\title{
PERMASALAHAN PENYUSUNAN TUGAS AKHIR MAHASISWA \\ BIDANG PENGKAJIAN SENI \\ PROGRAM STUDI PENDIDIKAN SENI KERAJINAN \\ FBS UNY
}

\author{
Abstrak \\ Oleh : \\ Iswahyudi, M.Hum.
}

Tujuan penelitian ini adalah untuk mendeskripsikan kendala yang dialami mahasiwa dalam penulisan proposal tugas akhir pendidikan seni kerajinan, strategi pembimbingan yang efektif untuk peningkatan kualitas penulisan proposal tugas akhir pendidikan seni kerajinan dan mendeskripsikan penulisan laporan penelitan yang berkualitas.

Metode Penelitian ini merupakan studi kasus untuk mengungkap kasus-kasus yang bersifat spesifik pada individu, kelompok, atau lembaga yang dilakukan secara intensif. Subjek penelitian ini adalah mahasiswa Program Studi Pendidikan Seni Kerajinan yang akan atau sedang menulis proposal TAS di bidang pendidikan dan pembelajaran seni kerajinan.Teknik pengumpulan data dalam penelitian ini dengan wawancara, dokumentasi, dan kuesioner.

Hasil penelitian menunjukkan perlunya upaya yang lebih terprogram untuk menyiapkan mahasiswa dalam menulis tugas akhir skripsi bidang pendidikan dengan lebih cepat dan lebih baik. Kesiapan mahasiswa dalam menulis proposal masih ditemukan multi kelemahan mulai dari masalah terkait metodologi penelitian, penulisan maupun subtansi keilmuan seni kerajinan. Untuk itu diperlukan workshop penulisan proposal penelitian untuk menyiapkan mahasiswa lebih awal menyusun proposal dengan baik.Proses pembimbingan skripsi terkendala oleh sulitnya bertemu dengan dosen pembimbing, dan masih ditemukan masalah teknis dalam hal penguasaan bahasa dan penulisan iulmiah yang baik dan benar. Untuk itu perlunya penataan mata kuliah metodologi penelitian dan seminar agar lebih banyak memberikan wawasan mahasiswa dalam menulis karya ilmiah dengan baik. Diupayakan setiap mata kuliah baik teori maupun praktik memberikan tugas kepada mahasiswa untuk membaca dan menulis dalam bentuk paper, resume, analisis dan sebagainya untuk dipresentasikan.

Kata kunci: Peningkatan Kualitas, Tugas Akhir Mahasiswa 


\title{
THE PROBLEMS OF THE FINAL TASK OF THE STUDENTS OF ARTS AND CRAFT EDUCATION DEPARTMENT FBS UNY
}

\author{
Abstrak \\ By: \\ Iswahyudi
}

The purpose of this study was to describe the constraints experienced by students in the final project in the writing of proposal, describe the effective coaching strategies for improving the quality of the final project and describe the writing of the research report .

Methods of this study was a case study to uncover the cases that were specific to individuals, groups, or institutions conducted intensively. The subjects were students of Arts Education Crafts that will or are writing a proposal TAS in the theme of education. Data collecting by interviews, documentation, and questionnaires.

The results showed that there were need more efforts to prepare students in writing final task faster and better. There were found multiple weaknesses in writing proposals related to the research methodology, and the substance of writing.. It required writing workshops to prepare students early in writing.Another problem is the difficulty in meeting the lecturer, and still found a technical problem in terms of mastery of the language and the writing. For that the need for structuring courses and seminars research methodology that provides more insight into the students in writing scientific works well. Each course pursued both theory and practice requires the students to read and write in the form of papers, resumes, analysis and so on to be presented.

Keywords: Improving quality, Final Project.

\section{PENDAHULUAN}

Rata-rata waktu kelulusan mahasiswa Program Studi Pendidikan Seni Kerajinan hampir lebih dari empat tahun. Waktu studi ini tentunya kurang sesuai dengan harapan, karena idealnya lulusan Sarjana Strara S1 memerlukan wakktu studi kurang dari 4 tahun.

Berdasarkan observasi, wawancara, dan menggali beberapa dokumen di Program Studi Pendidikan Seni Kerajinan, lamanya masa studi mahasiswa sebagian besar disebabkan karena lamanya waktu penulisan Tugas Akhir (TA). Terdapat beberapa dan bervariasi kasus-kasus yang dialami setiap mahasiswa, 
sehingga mengakibatkan waktu penulisan TA lebih dari satu semester, bahkan penyelesaian TA ada yang sampai memerlukan waktu dua tahun. Sekiranya perlu adanya refleksi yang mengarah pembenahan dan percepatan penyelesaian penyusunan TA.

Kenyataan menunjukkan bahwa lulusan Prodi Pendidikan Seni kerajinan FBS UNY rata-rata memiliki lama masa studi di atas lima tahun. Hambatan yang paling banyak dialami mahasiswa terutama dalam penulisan tugas akhir, baik tugas akhir skripsi (TAS) maupun tugas akhir karya seni (TAKS) adalah kesulitan menulis proposal penelitan.

Berawal dari itu, maka perlu adanya solusi yang merujuk pada kualitas penyusunan Tugas Akhir (TA) mahasiswa Program Studi Pendidikan Seni Kerajinan.

\section{TUGAS AKHIR SKRIPSI}

Seperti disebutkan dalam Pedoman Tugas Akhir pada Fakultas Bahas dan Seni UNY, untuk mengakhiri studi jenjang S1, mahasiswa FBS harus menempuh dan menyelesaikan tugas akhir. Tugas akhir ini dapat dibedakan menjadi Tugas Akhir Skripsi (TAS) dan Tugas Akhir Bukan Skripsi (TABS). Untuk mahasiswa Program Studi Pendidikan Seni kerajinan FBS, TAS merupakan karya tulis ilmiah mahasiswa di bidang seni kerajinan atau pengajarannya yang didasarkan pada hasil penelitian (Panduan TA FBS UNY, 2014: 1-2).

TAS merupakan karya tulis ilmiah mahasiswa di bidang bahasa, sastra, seni atau pengajarannya yang didasarkan pada hasil penelitian. TABS adalah karya tulis ilmiah yang didasarkan hasil analisis kritis terhadap fenomena ahasa, sastra, seni, atau pengajarannya. Disamping itu juga analisis terhadap suatu karya kreatif baik karya sendiri maupun karya orang lain. TABS juga dipertanggungjawabkan di depan dewan penguji. Tugas akhir adalah matakuliah yang bersifat wajib bagi semua mahasiswa. TAS berbobot 6 satuan kredit semester (SKS). Yang berfungsi untuk memberikan pengalaman kepada mahasiswa tentang penulisan karya ilmiah dan atau penelitian sesuai dengan spesialisasinya. Untuk menempuh TAS mahasiswa diharuskan memenuhi 
beberapa ketentuan seperti telah menempuh 110 SKS, IP sekurang-kurangnya 2.50, nilai D 10\% dari total sks yang harus ditempuh, mendapat rekomendasi dari penasehat akademik, minimal dua kali mengikti seminar ilmiah yang relevan dengan bidang studi, menempuh ujian, dan menyetujui dan menandatangani kontrak pembimbingan dengan masa kontak 18 bulan untuk TAS dan 12 bulan untuk TABS. (Panduan Tugas Akhir FBS UNY: 2011).

Setelah semua persyaratan tersebut terpenuhi mahasiswa membuat atau menyusun proposal yang merupakan rancangan kegiatan yang akan dilakukan. Proposal TAS baik kuantitatif maupun kualitatif pada prinsipnya mencakup pendahuluan, kajian teori atau acuan teori, metode penelitian, daftar pustaka, dan jadwal penelitian. Proposal disusun tidak atas bab-bab tetapi disusun atas sistematika sebagai berikut judul, latar belakang masalah, identifikasi dan pembatasan masalah, rumusan masalah tujuan penelitian, manfaat, kerangka teori, cara penelitian, jadwal penelitian, dan datar pustaka.

Penulisan tugas akhir skripsi merupakan tugas penulisan ilmiah. Sikap ilmiah seorang ilmuwan sebagai seorang peneliti atau penulis ilmiah tersebut menurut Bungin (2008) antara lain: (1) objektif, faktual, peneliti harus memiliki sikap objektif dan berdasarkan fakta; (2) open, fair, responsible, peneliti harus bersikap terbuka terhadap bebagai saran, kritik utnuk perbaikan. Disamping itu peneliti harus wajar, jujur, dalam pekerjaan ilmiahnya; (3) curios, wanting to know, sikap ingin tahu terhadap sesuatu yang diteliti dan pengetahuan baru; (4) inventif always, peneliti harus memiliki daya cipta, kreatif, dan senang terhadap inovasi.

\section{METODE PENELITIAN}

Penelitian ini merupakan studi kasus untuk mengungkap kasus-kasus yang bersifat spesifik pada individu, kelompok, atau lembaga yang dilakukan secara intensif. Penelitian ini berorientasi pada pengamatan suatu objek secara mendalam tentang latar belakang, status interaksi dengan lingkungan dan aspek lain yang sesuai dengan konteksnya. 
Subjek penelitian ini adalah mahasiswa Program Studi Pendidikan Seni Kerajinan yang akan atau sedang menulis proposal TAS di bidang pendidikan dan pembelajaran seni kerajinan. Lingkup penelitian ini adalah Program Studi Pendidikan Seni Kerajinan, Jurusan Pendidikan Seni Rupa, Fakultas Bahasa dan Seni Universitas Negeri Yogyakarta. Pelaksanaan penelitian pada semester genap tahun akademik 2013/2014 mata kuliah Tugas Akhir Skripsi (TAS) dan Tugas Akhir Bukan Skripsi (TAKS).

Teknik pengumpulan data dalam penelitian ini dengan wawancara, dokumentasi, dan kuesioner. Teknik wawancara dilakukan dalam penelitian untuk memperoleh data-data yang tidak dapat dicapai dalam pengamatan. Selanjutnya, teknik dokumentasi dimaksudkan untuk memperoleh data-data visual dari berbagai sumber. Kuesioner dilakukan untuk memperoleh data yang berkaitan dengan Kreatif, Produktif dan kualitas bembelajaran.

Untuk menganalisis data, dilakukan langkah-langkah penelitian yang akan dilakukan sebagai berikut: (1) mengidentifikasi dan merumuskan masalah, (2) menganalisis masalah, (3) merumuskan masalah, (5) mengolah dan menafsirkan data, (6) melaporkan hasil penelitian.

\section{HASIL DAN PEMBAHASAN}

Hasil penelitian menggunakan metode pengumpulan data melalui wawancara, observasi, dan dukumentasi kemudian dianalisis mendapatkan hasil sebagai berikut:

\section{a. Penyusunan proposal}

Hasil wawancara dengan mahasiswa yang mengambil tugas akhir skripsi bidang pembelajaran seni rupa dan kerajinan dapat disampaikan bahwa prosedur yang berkaitan dengan administrasi pengajuan proposal seperti format pengajuan judul, administrasi mengurus perizinan ke lapangan sudah difasilitasi oleh fakultas dan pengurusan lancar serta hasilnya sudah baik. Dari segi administrasi yang berkaitan dengan pengajuan judul, pengajuan pembimbing, dan perizinan terjun ke lapangan sudah dapat terlayani dengan baik. Dalam kaitan dengan pelayanan yang dilakukan admin jurusan dan fakultas dirasakan bagi mahasiswa sudah amat 
baik, ramah, dan memberikan pelayanan yang baik dan menyenangkan. Terkait dengan kepengurusan admin dan layanan petugas prodi dan fakultas menurut mahasiswa hasilnya memuaskan.

Sosialisasi panduan pembimbingan tugas akhir juga dilakukan pada saat mahasiswa mengajukan judul tugas akhir. Panduan tersebut dapat diambil stiap waktu di subag pendidikan. Selain itu, setiap pembimbing telah diberikan panduan tersebut dengan harapan pembimbing dapat membaca dan memperhatikan aturanaturan yang ada dalam penulisan tugas akhir, sehingga apabila ada mahasiswa yang kurang memperhatikan aturan penulisan tugas akhir, pembimbing dapat memperbaikinya sesuai dengan aturan yang diterapkan.

Pendapat mahasiswa terkait dengan proses pengajuan dan penentuan pembimbing masih banyak yang tidak sesuai dengan keinginan mahasiswa. Mahasiswa mengajukan alternatif pembimbing sebanyak tiga orang kemudian disetujuai oleh jurusan dua orang pembimbing dan ada yang satu pembimbing. Dari sudut pandang mahasiswa, penentuan pembinbingan skripsi ada yang sesuai dengan harapan mahasiswa sesuai pilihannya dan ada yang tidak sesuai dengan pilihan mahasiswa. Alasan ini memang sangat individual menurut pandangan dan keinginan dari sisi mahasiswa. Program studi memiliki pemikiran dan program penentuan pembimbing berdasarkan kompetensi dan pemerataan bukan sematamata memenuhi keinginan pilihan mahasiswa. Proses penentuan pembimbing ini menurut mahasiswa masih belum memberikan kepuasan sesuai harapan mahasiswa.

Penulisan proposal merupakan langkah awal yang menentukan kelancaran penulisan skripsi mahasiswa. Jika mahasiswa paham betul tentang permasalahan, tujuan skripsi, dan metodologinya jelas, maka penyusunan skripsi akan dapat berjalan dengan baik. Namun demikian, tidak jarang mahasiswa justru merasa kesulitan membuat rumusan masalah. Hal ini dikarenakan beberapa mahasiswa dalam melakukan observasi awal kurang terprogram dengan rinci sehingga kurang bisa menemukan titik-titik permasalahan di lokasi observasi. Selain itu, pada umumnya mahasiswa masih banyak kesulitan dalam menulis proposal dengan berbagai alasan, misalnya mahasiswa masih sulit untuk menulis dengan kalimat 
dan bahasa yang jelas dan baik. Hal itu disadari oleh mahasiswa bahwa mereka kurang dalam membaca buku dan jarang menulis. Melihat kenyataan itu perlu setiap mata kuliah harus memberikan tugas menulis dan presentasi. Dari sisi penentuan metode penelitian mahasiswa juga masih belum menguasai. Jika mahasiswa menentukan masalah dan tujuan penelitian seperti ini metode penelitian yang digunakan jenis metode apa, instrumen dan analisisnya menggunakan apa belum dikuasai dengan baik. Dalam konteks permasalahan seperti itu maka perlu prodi mengadakan lokakarya penulisan proposal untuk mahasiswa yang akan mengambil skripsi pada awal semester tujuh.

\section{b. Proses pembimbingan Tugas Akhir Skripsi}

Proses pembimbingan skripsi merupakan proses pembelajaran yang dilakukan secara individual antara dosen pembimbing dan mahasiswa penulis skripsi. Dalam proses ini mahasiswa mahasiswa mendapatkan arahan penulisan skripsi mulai dari yang berkaitan dengan teknis seperti sistimatika penulisan ilmiah, membuat instrumen, pengumpulan data, reduksi data, analisis data sampai penulisan laporan hasil penelitian.

Pembimbing juga memberikan cara mencari sumber referensi, membimbing penulisan dengan bahasa yang baik dan benar. Permasalahan yang dirasakan mahasiswa dalam proses pembimbingan sangat bervariasi tergantung kecerdikan mahasiswa dan siapa dosen pembimbingnya. Proses bimbingan skripsi diawali dengan konvirmasi ketemu dosen pembimbing, proses ini tidak semudah yang dipikirkan mahasiswa. Ada beberapa cara yang dilakukan mahasiswa untuk ketemu dosen pembimbing skripsi untuk menentukan kesepakatan bimbingan ada dosen yang dapat dan bersedia di telepon atau sms, ada pula yang tidak bersedia di telepon atau sms. Menurut mahasiswa ada dosen pembimbing yang di-SMS untuk minta waktu bimbingan tidak dibalas dan harus ketemu di kantor. Masih ditemukan dalam proses pembimbingan skripsi mahasiswa ketemu pembimbing masih sangat sulit karena dosen pembimbing tersebut super sibuk dan bimbingan skipsinya banyak harus antri dan setiap ketemu di kantor belum tentu ada waktu untuk bimbingan. 
Proses pembimbingan penulisan skripsi kependidikan judulnya kurang bervariasi. Banyak ditemukan bentuk pola metodologi penelitian deskriptif kualitatif yang hampir sama dari waktu kewaktu sehingga perlu. Hasil wawancara kepada mahasiswa ditemukan bahwa mahasiswa yang menulis skripsi tema pembelajaran masih minim penguasaan metode penelitian pembelajaran seperti action research, penelitian pengembangan, eksperimen dan sebagainya. Berkaitan dengan itu, mahasiswa masih asing dengan analisis statistik sederhana untuk menganalisis hasil penelitian eksperimen mereka. Dari pengalaman itu perlu menambahkan materi jenis penelitian untuk pendidikan dan materi statistik sederhana melalui mata kuliah penelitian atau ada mata kuliah statistik tersendiri untuk memperkaya wawasan mahasiswa sebagai calon guru.

Berkaitan dengan mencari sumber pustaka, sebenarnya mahasiswa program studi mempunyai tiga lingkup perpustakaan, yaitu: (1) perpustakaan universitas, dapat dimanfaatkan oleh mahasiswa setiap saat karena fasilitas yang sangat memadai dan dibuka setiap hari walaupun bukan hari kerja atau hari libur, (2) perpustakaan fakultas, perpustakaan ini dapat dimanfaatkan oleh mahasiswa pada setiap hari kerja, fasilitas yang adapun cukup memadai, dan (3) perpustakaan program studi, perpustakaan ini hanya dapat dimanfaatkan oleh dosen dan mahasiswa pada waktu-waktu tertentu karena petugas perpustakaan program studi belum ada petugas yang dapat melayani. Namun demikian, dalam mencari sumber pustaka sebagai referensi penulisan skripsi mahasiswa masih dirasakan sulit untuk mencari sumber acuan. Sebagai gambaran bagi mahasiswa yang mengambil tema skripsi tentang pembelajaran kepada anak usia dini, mencari sumber pustaka di perpustakaan fakultas FBS dan perpustakaan pusat UNY masih kesulitan, padahal UNY perguruan tinggi bidang kependidikan. Ada fenomena yang disampaikan mahasiswa yang cukup tidak nyaman dan kurang setuju bagi mahasiswa adalah masuk perpustaakan FBS mahasiswa tidak boleh membawa laptop dan kamera dengan berbagai alasan. Hal ini tentunya kurang mendukung kelancaran studi mahasiswa. Pengalaman penulis masuk perpustakaan di mana saja pengunjung/pembaca boleh membawa laptop dan kamera untuk memberikan kesempatan yang luas bagi pembelajar untuk mengakses pengetahuan. Solusi 
yang dilakukan mahasiswa menghadapi permasalahan tersebut dengan cara mencari sumber tersebut dengan berkunjung ke perpustakaan lain seperti perpustakaan Fakultas Ilmu Pendidikan, PGSD, dan PGAUD. Demikian juga mahasiswa mencari sumber buku acuan yang berkaitan dengan substansi materi seni rupa dan kerajinan masih dirasakan sangat sulit sehingga mahasiswa disarankan pembimbing untuk mencari referensi di perpustaakan lain seperti perpustakaan ISI Yogyakarta, perpustakaan UGM, perpustakaan daerah, dan sebagainya.

Pembimbingan berkaitan dengan pembuatan instrumen, pengumpulan data, dan analisis data untuk membuat laporan hasil penelitian. Mahasiswa banyak yang belum memahami dengan baik bagaimana membuat instrumen penelitian untuk pengumpulan data dan bagaimana peneliti sebagai human instrumen belum dipahami dengan baik. Pembimbing memberikan bimbingan membuat pedoman wawancara, observasi dan dokumentasi. Setelah instrumen tersusun dengan baik mahasiswa dibimbing cara mengumpulkan data dan anlisis data secara berkelanjutan setiap kali bimbingan. Masih ditemukan metode penelitian yang sama dan analisis data yang sama dalam kurun waktu yang relatif panjang. Untuk mengembangkan wawasan mahasiswa tentang metode penelitian mahasiswa diarahkan dan dibimbing untuk menggunakan pendekatan penelitian yang bervariasi baik deskriptif kualitatif maupun kuantitatif dengan analisis statistik dan analisis campuran kualitatif dan kuantitatif.

\section{c. Penulisan laporan penelitian}

Proses pembimbingan penulisan laporan hasil penelitian dilakukan pembimbingan beberapa kali untuk mendapatkan laporan hasil yang dapat dipertanggungjawabkan kebenaran ilmiahnya. Mahasiswa masih banyak yang mengalami kendala penulisan dari aspek teknis dan penggunaan tata bahasa Indonesia yang baik dan benar. Secara teknis mahasiswa dalam menulis laporan hasil penelitian telah disiapkan panduan penulisan laporan hasil penelitian dalam bentuk skripsi yang jelas apakah mahasiswa memilih format laporan jenis penelitian kuantitatif atau kulaitatif. Meskipun demikian masih banyak ditemukan 
kesulitan dalam penyajian laporannya. Mahasiswa masih kurang cermat pada penulisan sistimatika urutan bab, subbab, paragraf, kalimat, dan anak kalimat. Secara umum mahasiswa kita masih lemah dalam penguasaan penggunaan bahasa ilmiah dalam menulis skripsi.

Pembimbingan penulisan laporan masih dirasakan ada kendala penguasaan subtansi akademik sesuai bidang temuan penelitiannya. Mahasiswa masih banyak yang belum jelas dengan apa yang ditemukan dan pembahasan terhadap temuan penelitian tersebut. Subtansi keilmuan dalam bidang seni rupa dan kerajinan masih kurang dan mencari sumber referensi tentang seni rupa dan kerajinan masih dirasakan sangat sulit. Sumber buku acuan pada prinsipnya tidak terlalu sulit hanya mahasiswa banyak yang tidak mau mencari sumber di perpustakaan lain termasuk mengakses melalui dunia maya. Di dunia maya tersedia berbagai sumber referensi yang dapat diakses baik dalam bentuk artikel ilmiah maupun buku PDF yang dapat diakses gratis.

Dalam aspek bahasa masih banyak mahasiswa yang menulis laporan penelitian menggunakan kaidah bahasa yang belum jelas subjek, predikat, dan objek kalimatnya. Dalam aspek bahasa pembimbing harus masih banyak memberikan masukan aspek bahasa agar tulisan lebih baik keterbacaannya. Kelemahan penggunaan bahasa disebabkan oleh kurangnya budaya baca mahasiswa dan kurangnya latian menulis baik itu tulisan ilmiah atau tulisan fiksi yang dapat mengembangkan kemampuan menulis. Pembimbing masih banyak mengarahkan dan memperbaiki kalimat. Jika penulisan kalimat terlalu lemah banyak yang salah disarankan untuk dieditkan pada ahli bahasa sehingga memperlancar proses penyusunan laporan hasil penelitian.

\section{d. Kendala penulisan tugas akhir skripsi mahasiswa}

Kendala yang ditemukan dalam penulisan tugas akhir skripsi mulai dari penulisan proposal sampai penulisan laporan hasil sangat bervariasi. Seperti yang disampaikan dalam latar belakang masalah penelitian ini secara umum mahasiswa seni kerajinan lemah dalam budaya baca dan kurang tertarik pada mata kuliah yang bersifat teoretik. Ada fenomena menarik yang harus dipelajari ada 
mahasiswa yang kuat dalam berkarya seni dan lemah menulis atau sebaliknya ada mahasiswa yang kuat dalam karya tulisnya dan lemah dalam berkarya seni. Yang lebih berat lagi adalah menghadapi mahasiswa yang lemah dua-duanya baik menulis maupun berkatrya seni. Dari pengalaman itu perlu adanya upaya sinergik yang harus dilakukan prodi melalui perbaikan kurikulum dan sistem pembelajaran yang dapat mengembangkan kompetensi mahasiswa dalam menulis ilmiah maupun berkarya seni, serta bimbingan karier mahasiswa untuk diarahkan sesuai dengan bakat dan pilihannya.

Kendala yang dialami mahasiswa masih menyeluruh paling banyak muncul adalah mahasiswa masih kesulitan mencari dan menemukan permasalahan penelitian yang akan ditulis. Setelah permasalahan ditemukan mereka kesulitan menentukan judul penelitian baik dari segi bahasa maupun substansi yang berkaitan dengan metodologi penelitian apakah kualitatif atau kuantitatif. Mahasiswa masih menemukan kesulian teknis penulisan proposal maupun skripsi, kesulitan metodologi terutama pada analisis data. Dari kendala metodologi itu, akhirnya banyak mahasiswa yang menggunakan metode penelitian dan analisis meniru metode dan analisis hasil penelitian terdahulu seperti skripsi yang sudah ada di perpustakaan.

Kendala berikutnya adalah proses mencari tempat penelitan apakah di sekolah atau di industri. Mahasiswa merasakan kesulitan proses pembimbingan mulai dari sulitnya ketemu dosen pembimbing karena sibuk dan padatnya acara dosen tersebut. Kendala yang berarti bagi mahasiswa adalah mereka yang mengambil skripsi dalam bidang pendidikan belum pernah mendapatkan metode penelitian kuantitatif dan analisis statistik. Karena mahasiswa yang mengambil skripsi pembelajaran membutuhkan analisis statistik. Kendala selanjutna mahasiswa yang mengambil skripsi pembelajaran di sekolah sulitnya menentukan jadwal waktu untuk eksprerimen di kelas karena sekolah punya program dan jadwal yang ketat dan tidak sesuai dengan jadwal penelitian mahasiswa sehingga sulit bagi mahasiswa untuk mengambil data di lapangan. 


\section{e. Rekomendasi}

Sesuai dengan permasalah dan tujuan penelitian serta temuan hasil penelitian percepatan penulisan tugas akhir skripsi dan dalam kerangka untuk perbaikan sistem pembimbingan skripsi yang baik dan cepat di masa yang akan datang maka perlu memberikan rekomendasi sebagai berikut:

1) Sebelum mahasiswa menulis skripsi sebaiknya ada program workshop penulisan proposal untuk memberikan kesiapan lebih awal mahasiswa melaksanakan penulisan tugas akhir skripsi. Workshop tersebut diisi materi tentang teknis penulisan proposal, bagaimana menulis kajian pustaka yang sesuai/mendukung tema/judul penelitian, metodologi penelitian, sistem pembimbingan, dan penulisan laporan penelitian.

2) Mahasiwa diberikan pengarahan dari program studi sebagai mahasiswa bidang pendidikan seni kerajinan seyogyanya menulis skripsi bidang pendidikan dan pembelajaran seni rupa dan kerajinan untuk memperkuat kompetensi pedagogik sebagai mahasiswa bidang pendidikan seni kerajian dan akan menjadi guru bidang seni rupa dan kerajinan.

3) Program Studi Pendidikan Seni Kerajinan membuat format program kontrak pembimbingan TA dengan target dan waktu yang jelas serta sistem monitoringnya sehingga pembimbingan skripsi dapat diselesaikan dalam waktu satu semester dengan baik.

4) Dosen pembimbing menyediakan waktu khusus dan terjadwal yang memang digunakan untuk melayani mahasiswa bimbingan TA, sehingga mahasiswa tidak kesulitan ketemu dosen untuk bimbingan.

5) Pelaporan hasil penelitian disampaikan dalam bentuk hard copy untuk keperluan dukumen prodi dan fakultas, dan laporan dan artikel jurnal dalam bentuk file yang siap dicetak atau diupload ke internet.

6) Perlu penambahan koleksi buku metodologi penelitian, buku kependidikan, dan buku seni rupa dan kerajinan pada perpustakaan jurusan atau fakultas.

7) Perlunya mata kuliah penelitian pendidikan yang mengajarkan berbagai model penelitian pendidikan termasuk analisis statistik tidak hanya kualitatif saja. 
8) Perlu perubahan kurikulum yang menempatkan mata kuliah Penelitian Seni ditawarkan sebelum mahasiswa melakukan PPL-KKN agar mahasiswa dapat lebih awal memahami bagaimana menulis proposal, melakukan penelitian, dan membuat laporan penelitian.

\section{KESIMPULAN}

Dari uraian pada pendahuluan dan latar belakang masalah yang disampaikan di depan dan berdasarkan hasil penelitian dapat disimpulkan bahwa perlu ada upaya yang lebih terprogram dengan baik untuk menyiapkan mahasiswa dalam menulis tugas akhir skripsi bidang pendidikan dengan lebih cepat dan lebih baik. Upaya percepatan penulisan tugas akhir skripsi dalam bidang pembelajaran tersebut dapat disimpulkan sebagai berikut:

Mahasiswa masih memiliki banyak kelemahan dalam menulis proposal dalam hal metodologi penelitian dan penulisan subtansi keilmuan seni kerajinan. Untuk itu diperlukan workshop penulisan proposal penelitian untuk menyiapkan mahasiswa lebih awal menyusun proposal dengan baik.

Mahasiswa menemui kendala dalam proses pembimbingan karena ada dosen yang sulit ditemui. Untuk menjembatani dan mengatasi kesulitan tersebut perlu adanya jadwal pembimbingan yang jelas dan pasti yang ditetapkan prodi sehingga mahasiswa tidak kesulitan ketemu dosen pembimbing.

Masih ditemukan masalah teknis dalam penulisan laporan penelitian yaitu kendala penguasaan bahasa dan penulisan iulmiah yang baik dan benar. Untuk itu mata kuliah metodologi penelitian dan seminar diharapkan lebih banyak memberikan wawasan kepada mahasiswa dalam menulis karya ilmiah dengan baik. Diupayakan setiap mata kuliah baik teori maupun praktik memberikan tugas membaca dan menulis dalam bentuk paper, resume, analisis dan sebagainya untuk dipresentasikan. 


\section{DAFTAR PUSTAKA}

Burhan Bungin. 2008. Penelitian Kualitatif. Jakarta: Kencana Prenada Media group.

.2008. Analisis data penelitian kualitatif. Jakarta: Rajawali

Fakultas Bahasa dan Seni UNY.2011.. Panduan Tugas Akhir. Yogyakarta: FBS UNY.

Hamalik, Oemar. 2005. Kurikulum dan Pembelajaran. Jakarta: Bumi Aksara.

Universitas Negeri Yogyakart . 2014. Pedoman Tugas Akhir Skripsi dan Bukan Skripsi. 